International Journal of Public Finance
E-ISSN: $2548-0499 \quad$ DOI: $10.30927 /$ ijpf.327882
Vol./Cilt: 2 | Issue/Sayı: 2 | (2017), pp. $226-244$
journal homepage: http://dergipark.gov.tr/ijpf

\title{
Vergi Cennetleri İle Mücadele Aracı Olarak Şeffaflık: “OECD- BEPS 5 Numaralı Eylem Planı (2015 Nihai Raporu) Temelinde Bir Çalışma"
}

\author{
Transparency: As An Instrument To Combat With Tax Havens \\ A Study On The OECD-BEPS Action 5 (2015 Final Report)"
}

\author{
Zeynep Nihan ÇAMURCU ${ }^{1}$
}

\section{ARTICLE INFO}

Received: 11.07.2017

Received in revised

form: 17.11.2017

Accepted: 08.12.2017

Available online:

05.01.2018

\section{JEL classification:}

$\mathrm{H} 20, \mathrm{H} 26, \mathrm{H} 25$

\section{Keywords:}

Transparency, Tax

Havens, BEPS Action

5, Harmful Tax

Practices, Tax

Evasion, Tax Rulings

\begin{abstract}
A B S T R A C T
Apart from the problem of use of the tax havens in the financing of international crimes, the non-taxation of high amounts of funds brings some other problems such as reduction of the budget revenues of the states and the restriction of public expenditures. Therefore, the "tax havens" has become serious and current problem that needs to be resolved for the world economy.

The Organisation for Economic Co-operation and Development (OECD) published a report in 1998 and declared a war against harmful tax competition. This report was the first wave of fighting against harmful tax competition. However, the proliferation of tax havens led to exist a new wave -especially after the global financial crisis- in combat with tax havens. This second wave was named "transparency" by OECD.

The "transparency" revealed in OECD Base Erosion Profit Shifting -5 Action (2015 final report), which can be used as an instrument in fighting against tax havens, has be examined in the study.
\end{abstract}

MAKALE BígGisi

Alındı: 11.07.2017

Gözden geçirilmiş

alındı: 17.11 .2017

Kabul: 08.12.2017

Yayın: 05.01.2018

JEL Kodu:

$\mathrm{H} 20, \mathrm{H} 26, \mathrm{H} 25$

\section{Ö Z E T}

Vergi cennetlerinin uluslararası suçların finansmanında kullanılması sorunu bir yana, bu ülkelerin vergiden kaçınma ve vergi kaçırma amaçlarıyla kullanılarak yüksek miktarlardaki fonların vergilendirme dışında bırakılması, devletlerin bütçe gelirlerinin azalması ve kamu harcamalarının kısıtlanması gibi birtakım olumsuz sonuçları beraberinde getirmiştir. Bu nedenle, "vergi cennetleri", dünya ekonomisi için ciddî ve güncel bir sorun olarak, giderek artan bir öneme sahiptir.

\footnotetext{
${ }^{1}$ Araş.Gör., Marmara Üniversitesi, Hukuk Fakültesi, Mali Hukuk A.D., zeynepnihanaladag@hotmail.com.
} 
Anahtar Kelimeler: Vergi Hukuku, Vergi Cennetleri, Şeffaflık, Zararlı Vergi

Rekabeti, Vergiden Kaçınma
Vergi cennetlerinin gelişimi; 1998'de Ekonomik Kalkınma ve İşbirliği Örgütü tarafından başlatılan "vergiden kaçınma/haksız vergi rekabeti" ile savaşta yeni bir dalganın gelişine -özellikle küresel finansal krizin ardından- neden olmuştur. Bu ikinci dalga Ekonomik Kalkınma ve İşbirliği Örgütü tarafından "şeffaflık" olarak adlandırılmıştır.

Şeffaflı̆ın geliştirilmesi amacını taşıyan BEPS (Base Erosion Profit Shifting: Matrah Aşındırma ve Kâr Aktarımı)- 5 Numaralı Eylem Planı (2015 Nihai Raporu) ile belirli kategorilerdeki idari kararlara ilişkin bilgilerin bu kararlardan etkilenen ülkeler ile değiştirilmesi gerekliliği ortaya konmuş, bilgi değişimine konu kararların çerçevesi çizilmiştir . Çalışmada "şeffaflık" BEPS- 5 Numaralı Eylem Planı temelinde incelenmiştir.

\section{Giriş}

Vergi cennetleri; dünya ekonomisi için ciddi ve güncel bir sorun olarak artan bir öneme sahip iken, ne ulusal ne de uluslararası vergi hukuku doktrininde konu aynı ciddiyetle dikkate alınmamaktadır (Kudrle, 2016: 1154). Bir Amerika Birleşik Devletleri kurumu olan "Citizens for Tax Justice" in çokuluslu beş yüz işletme nezdinde gerçekleştirdiği araştırma, her dört işletmeden üçünün vergi cennetlerinde aktif oldukları gerçeğini ortaya koymuştur (Bennedsen\&Zeume, 2015: 1).

Vergi cennetlerinin terörün finansmanı, kaçakçılık gibi suçlarda kullanılması sorunu bir yana, yüksek miktardaki fonların vergilendirilmemesi, devletlerin bütçe gelirlerinin azalması ve kamu harcamalarının kısıtlanması gibi ciddi problemleri beraberinde getirmiştir (Arslan, 2011: 42). Bununla birlikte, OECD'nin ve diğer uluslararası kuruluşların farklı tarihlerde yayınlamış olduğu listeler dikkate alındığında; vergi cennetlerinin sayısında artış olmasının yanı sıra, zararlı vergi uygulamalarını destekleyici düzenlemelerin de yürürlüğe girdiği görülmektedir.

Vergi cennetlerinin gelişimi; 1998 'de OECD tarafından başlatılan "vergiden kaçınma/haksız vergi rekabeti" ile savaşta yeni bir dalganın gelişine -özellikle küresel finansal krizin ardından- neden olmuştur (Kudrle, 2016: 1154). Bu ikinci dalga OECD tarafından "şeffaflık" olarak adlandırılmıştır.

BEPS - 5 Numaralı Eylem Planı (2015 Nihai Raporu) "şeffaflığın geliştirilmesini" amaç edinmiş ve bu amaca hizmet edecek bir takım araçlar geliştirmiştir. Çalışmada "şeffaflık" kavramının vergi hukuku bakımından taşıdığı anlam aydınlatılmaya çalışılacak ve şeffaflığın geliştirilmesi için BEPS- 5 Numaralı Eylem Planı Nihai Raporunda öngörülen düzenlemeler irdelenecektir.

\section{2. "Vergi Cennetleri" Sorunu}

\subsection{Kavram ve Karakteristik Özellikler}

İngilizcede vergi sığınağı anlamına gelen "tax haven" sözcüğünün karşılığı olarak Türk literatürüne giren "vergi cennetlerinin", ne uluslararası hukuk ne de Türk Vergi Hukuku doktrininde genel kabul gören ortak bir tanımı yoktur (Öz, 2005:123). 
Genel kabul gören ortak bir tanımı bulunmamakla beraber vergi cennetleri; vergi oranları ve diğer vergi avantajları ile yatırımcılarına hitap edecek şekilde düzenleme yapılan yerler, yatırımcılarına artan uluslararası rekabet koşullarında vergiden kaçınmak için çeşitli fırsatlar sunan yerler olarak da tanımlanabilir (Öztürk\&Ülger, 2016: 238).

Bir başka yazara göre vergi cennetleri, "daha çok yatırımcıyı ülkesine çekmek için gelir, servet, sermaye ve harcama unsurlarından hiç vergi alınmayan veya çok düşük oranlarda vergi alınan veyahut vergilendirmede muafiyet, istisna ve indirim hadlerinin çok geniş olarak uygulandığı; işlemlerin gizlilik içinde yapılabildiği ülke ya da yerlerdir" (Pehlivan \& Öz, s.123).

OECD, yatırımcılarına idari kolaylıklar sağlamanın yanında, düşük oranda vergilerin uygulandığı ya da hiç verginin olmadığı bir ortam sağlayan ve banka gizliliği gibi nedenlerle bilgi değişiminin olmadığı ülkeleri "vergi cenneti" olarak tanımlamaktadır (OECD Glossary of Tax Terms, 2017).

Pek çok farklı yazar tarafından farklı biçimlerde yapılan vergi cennetleri tanımlarında yer alan ortak özellikler, vergi cennetlerinin yatırımcılarına sıfır oranında veya düşük oranda vergi uygulamaları ve mükelleflerin bilgilerini diğer vergi idareleri ile paylaşmada isteksiz olmalarıdır (Weichenrieder\&Xu, 2015:2).

Doktrinde kavramı açıklamaya yönelik tanımlar çoğunlukla klasik anlamda vergi cennetlerini, bir diğer ifade ile "saf nitelikli vergi cennetlerini" tanımlamaktadır ki vergi cennetleri içerisinde sayısal çoğunluğu bu tip vergi cennetleri oluşturmaktadır. Saf nitelikli vergi cennetleri; sıfır oranında veya düşük oranda vergi uygulamalarını güvenilir yerel kurumsal yapılar ile destekleyerek, yabancı kaynaklı fonları diğer vergi idarelerinin bilgisinden sakınarak bu fonların vergilendirilmeksizin küresel ekonomiye yeniden kazandırılmasını sağlar (Kudrle, 2016: 1155). Hukuki, idari veya adli faaliyetlerde şeffaf olunmaması ve gerçek bir faaliyetin zorunlu olmaması, yatırımcılara yatırımlarında veya işlemlerinde vergi kaçırma olanağı yaratır. Saf nitelikli vergi cennetleri çoğunlukla küçük ölçekte ekonomilere sahip ada ülkeleridir. Bunlara örnek olarak İngiliz Virgin Adaları, Bahamalar ve Cayman Adaları verilebilir. "Karma nitelikli vergi cennetleri" olarak adlandırılan vergi cennetleri saf nitelikli vergi cennetlerinin aksine yüksek oranlı bir kurumlar vergisi sistemine sahiptir (Kudrle, 2016: 1155). Bu tip vergi cennetlerinde saf nitelikli vergi cennetlerine göre daha yüksek vergi oranları uygulanmakla beraber, bu ülkeler yatırımcılarına belirli tip yerel uzmanlık gerektiren faaliyetlerin farklı bileşimlerini sunmaktadır (Kudrle, 2016: 1155). Karma nitelikli vergi cennetlerinin en bariz örnekleri İrlanda ve İsviçre'dir.

OECD 1998 tarihli " Zararlı Vergi Rekabeti” isimli raporunda bir ülkenin vergi cenneti olarak tanımlanması için şu temel karakteristik özellikleri taşıması gerektiği yönünde görüş bildirmiştir:

- Düşük/sıfır oranlı vergi uygulaması

- Şeffaf olmayan vergi uygulamaları

- Etkin bilgi değişiminden yoksunluk

- Ekonomik özden yoksun faaliyet 
1998 yılı raporunda ortaya konan özellikler içerisinde belirleyici olan özellik, "düşük veya sıfır oranlı vergi uygulamalarıdır". Ancak OECD bu yaklaşımı, 2001 tarihli İlerleme Raporu ile revize etmiş, düşük oranlı veya sıfır oranında vergi uygulamaları ve ekonomik özden yoksun faaliyetin vergi cennetlerini belirleyici karakteristik özellikler olarak değerlendirilemeyeceğini ifade etmiştir. Bu görüş değişikliğinin ardından ifade edilebilir ki, OECD nezdinde bir ülkenin vergi cenneti olarak nitelendirilebilmesi için yalnızca etkin bilgi değişiminden ve şeffaflıktan yoksun olması yeterlidir. Bu durum şeffaflığın, vergi cennetleri ile mücadelede işlevsel bir araç olarak değerlendirilmesine neden olmuştur.

\subsection{Vergi Cennetlerinin Kullanım Amaçları ve Zararlı Ekonomik Etkileri}

Günümüz dünyasında herhangi bir mükellef, vergilendirilmek istediği ülkeyi seçme konusunda fiili bir özgürlüğe sahiptir. Bu özgürlük nedeniyle mükellefler, vergi matrahlarını azaltacak biçimde faaliyetlerini istedikleri yerde konumlandırma imkanına sahip olmaktadır.

Vergi cennetleri genel itibariyle yolsuzluk, vergi kaçırma, kaçakçılık gibi yasadışı aktiviteler ve bu aktiviteler neticesinde elde edilen kazançların aklanması ve vergiden kaçınma gibi amaçlar için kullanılmaktadır (Oxfam, 2000: 1). Özellikle çok uluslu işletmelerce vergi cennetlerinin vergiden kaçınma ve vergi kaçırma amaçları için kullanılması, gelişmiş ve gelişmekte olan ülkeler bakımından vergi cennetlerinin ciddi bir tehdit olarak görülmesine neden olmuştur.

Vergi cenneti ülkelerin vergiden kaçınma veya vergi kaçırma amacı ile kullanılması pek çok farklı faaliyet türü ile mümkün olabilir. Vergi cennetleri ile yapılan ithalat ve ihracatta maliyet bedelleri düşürülerek veya yükseltilerek vergi matrahı aşındırılabilir (Öztürk\&Ülger, 2016:243). Öte yandan vergi cennetlerindeki şirketlerden danışmanlık, proje, organizasyon ve Ar-Ge gibi hizmetler alındığı ileri sürülerek sahte belge düzenlemek veya kullanmak suretiyle vergi matrahının azaltılması mümkün olabilir (Bilici, 2004: 601). Transfer fiyatlandırması yoluyla vergi cennetlerinin matrah azaltıcı biçimde kullanılması oldukça sık rastlanan bir durumdur. Aynı çok uluslu grubun üyesi olan iki şirketin mal veya hizmet alışverişinde bulunması ve bu alışveriş için fiyat belirlemesi çok tabiidir ki faaliyet bu haliyle hukuka aykırı olarak addedilemez. Fakat iki ilişkili şirket, birbirleriyle ticaret yaptığında toplam vergi matrahını en aza indirgemek için, ticaretin gerçekleştirildiği fiyatı gerçeğe aykırı biçimde belirleyebilirler. Bu örnekte, vergilerin düşük oranda veya sıfır oranında olduğu bir vergi cennetinin kullanılması, olabildiğince az miktarda vergi yükünün yüklenilmesine yardımcı olur. Vergi cennetlerinin vergiden kaçınma ve vergi kaçırma amacıyla kullanımına başka örnekler de vermek mümkündür. Örneğin, turizm ile iştigal eden şirketlerin vergi cennetlerinde işlemlerini gerçekleştirmesi, onlara birtakım vergisel avantajlar sağlayabilir (Öztürk\&Ülger, 2016: 244). Örneğin, Bermuda'da otel inşası ve işletmesinden elde edilen gelirler otuz yıl gibi uzun bir süre ile vergiden istisna edilmiştir (Öztürk\&Ülger, 2016: 244). Gemi taşımacılığına ilişkin yasal düzenlemelerin avantajı olduğu Panama, Liberya, Kıbrıs gibi ülkeler ise uluslararası gemi taşımacılığı şirketlerini, faaliyetlerini bu ülkelerde konumlandırma hususunda teşvik etmektedir (Starchild, 2016: 19) 
Yukarıda bahsi geçen örneklerde, faaliyet neticesinde vergilendirilebilir kazancın vergi cennetlerine aktarılmasından etkilenen ülkelerin bütçe gelirlerinde kayıp yaşayacağı açıktır. Nitekim, vergi cennetlerinde iştiraki bulunan şirketlerin vergiye tabi gelirlerini vergi cennetlerine taşıması kolaydır. Öte yandan şirketlerin vergi cennetlerinde elde ettikleri gelirin tespiti ve bu gelirin vergilendirilmesi, vergi cennetlerinin sunduğu imkanlar dolayısıyla çoğunlukla ertelenmekte veya hiç mümkün olmamaktadır (Desai\&Foley\&Hines, 2004: 22). Bunun gibi lokal olumsuz ekonomik etkilerin yanı sıra vergi cennetlerinin, vergi kaçırma ve vergiden kaçınma amacı ile kullanılması küresel düzeyde de olumsuz ekonomik etkileri beraberinde getirmektedir (Arslan, 2011:42). Öyleki, offshore finans merkezlerinin 2007'de ortaya çıkan krize katkıda bulunduğu düşünülmektedir (Europen Parliament, 2013: 9). 2008 küresel krizi, vergi cennetlerinin gelişmiş ve gelişmekte olan ülkelerin ekonomileri üzerindeki giderek artan zararlı etkilerini görme fırsatı vermiştir (Karakurt, 2016: 320). Gelişmekte olan ülkelerin vergi cenneti ülkelerden kaynaklanan kayıplarının, gelişmiş ülkelerden aldığı yardımların üç katı civarında olduğu tahmin edilmektedir (Öztürk\&Ülger, 2016: 244).

Vergi kaçakçılı̆ı, yıllık ortalama dünya finansal zenginliğinin yaklaşık \% 8'ini oluşturmaktadır (Zucman, 2015: 19). Çok uluslu işletmelerin denizaşırı ülkelerde gerçekleştirdikleri faaliyet dolayısıyla elde ettikleri nakit miktarı son yıllarda önemli ölçüde artarak sekiz trilyon ABD dolarına ulaşmıştır (Zucman, 2016: 66 ). Ancak bu miktarın, vergi cennetlerinin şeffaf olmadığı ve dolayısıyla vergi cennetlerindeki kayıtlara ulaşılamadığı gerçeği dikkate alındığında sadece tahmini olduğunu söylemek mümkündür. Nitekim bir başka yazar James Henry, bahsedilen nakit miktarının Zucman'ın iddiasının aksine, yirmi bir trilyon ABD dolarından az olmamakla birlikte otuz beş trilyon ABD doları civarında olduğunu iddia etmiştir (Murphy, 2017:22).

Vergi cennetleri hakkında Michigan Üniversitesi'nde yapılan güncel bir çalışmada elli iki ülkeden on yedi bin üç yüz otuz bir firma ve onların uluslararası iştiraklerinin kamuya açık verilerinden faydalanılmış ve şu çıktılar elde edilmiştir: ilk olarak yurt içi kurumlar vergisi oranındaki 1 puanlık bir azalma vergi cennetinde bağı iştirakleri olmayan firmaların hisse değerlerinde \%1,2'lik bir artışa neden olurken, vergi cennetlerinde iştirakleri olan firmalar artıştan etkilenmemiştir (Bennedsen\&Zeum, 2015: 1). İkincisi, diğer ülkelerle vergi cennetleri arasında bilgi değişimi anlaşmalarının imzalanması yoluyla şeffafığın artırılması, etkilenen firmaların ortalama hisse değerlerini \%2,5 oranında artırmıştır (Bennedsen\&Zeum, 2015: 1). Üçüncü olarak vergi cennetlerinde karmaşık firma yapısına sahip işletmeler için vergi cennetlerinin yarattığı olumlu ekonomik etki daha güçlüdür (Bennedsen\&Zeum, 2015: 1). Son olarak firmalar, iştiraklerini bilgi değişimi taahhüdünde bulunan vergi cennetlerinden bilgi değişim taahhüdünde bulunmayan vergi cennetlerine yönlendirme eğilimde olduğunu göstermiştir (Bennedsen\&Zeum, 2015: 1). Bu sonuçlar vergi cennetlerindeki iştiraklerin, saf vergi tasarrufunun ötesinde bir gizleme faaliyeti için kullanıldığını ortaya koymuştur (Bennedsen\&Zeum, 2015: 1). Şüphesiz varılan bu netice vergi cennetleri dolayısıyla bütçe gelirleri azalan ülkeleri bilgi değişimi yoluyla şeffaflaşma hususunda işbirliği içerisinde bulunmaya yöneltmiştir.

G20 (Group of 20: 20 Maliye Bakanı ve Merkez Bankası Başkanı Grubu) liderleri 2009 yılında vergi cennetleri de dahil olmak üzere işbirliği içerisinde olmayan ülkelere 
karşı harekete geçme kararı almış ve bu kararı, ilgili bölümde incelendiği üzere, bir dizi eylem takip etmiştir.

\section{Vergi Cennetleri ile Mücadelede Şeffaflığın Geliştirilmesi Süreci}

OECD zararlı vergi uygulamalarına karşı, 1998 yılında "Zararlı Vergi Rekabeti" raporu ile bir savaş başlatmış ve bu savaşta 2013 yılında ikinci ciddi adım atılmıştır. OECD mevcut kuralların, vergilendirilebilir kazançların fiili faaliyetin gerçekleştiği yerlerden farklı yerlere dağıtılmasına izin verip vermediğini araştırmak üzere, "Matrah Aşındırma ve Kar Aktarımı" projesini başlatmış ve 19 Temmuz 2013'de ulusal ve uluslararası bir dizi eylem planı içeren bir rapor yayınlamıştır (Harm, 2013: 123).

G8 (Group of 8: Sekizler Grubu) ülkeleri, Haziran 2013 toplantısında, bilgi paylaşımı konusunda daha fazla şeffaflık sağlamak ve modern çağda uluslararası vergi standartları geliştirmek için kararlı adımlar atacaklarını taahhüt etmiş ve OECD’yi desteklediklerini duyurmuşlardır (Harm, 2013:123). Akabinde G20 sanayileşmiş ülkeler grubu, Temmuz 2013 toplantısında, BEPS projesini devreye sokmuştur.

BEPS, üç temel konu çerçevesinde on beş farklı hususta eylem planını kapsamaktadır. Bahsi geçen üç temel konu şunlardır: Yabancı kaynaklı faaliyetlere etki eden iç hukuk normlarının uyumlu hale getirilmesi, özün önceliği ilkesi çerçevesinde ekonomik öze ilişkin faaliyetin tespitine ilişkin mevcut uluslararası standartların pekiştirilmesi ve şeffaflığın kati biçimde geliştirilmesi.

OECD’nin, 1998 tarihli raporunda, bir ülkenin vergi cenneti olarak kabul edilmesinde öngörülen kriterlerden birinin "şeffaf olmayan vergi uygulamaları" olduğuna daha önce değinilmiştir. OECD, şeffaflık konusunda 1998 tarihinden bu yana yapmış olduğu çalışmaları "Şeffaflık ve Özün Dikkate Alınması Suretiyle Zararlı Vergi Uygulamalarıyla Etkili Mücadele" isimli BEPS- 5 Numaralı Eylem Planı ile hızlandırmış ve 2015 yılında nihai raporunu yayınlamıştır.

2015 tarihli Nihai Rapora göre OECD, 1998 yılında haksız vergi rekabeti üzerine yayınladığı rapor ile vergi cennetleriyle mücadelede başladığı yolda, bugün varılan noktaya kadar pek çok aşama kat etmiştir. Bu aşamaları ve kapsamlarını şu şekilde özetlemek mümkündür;

1998 raporunda zararlı vergi uygulamaları üç temel alanda değerlendirilmiştir. Bunlar; OECD ülkelerindeki tercihli vergi rejimleri, vergi cennetleri ve OECD üyesi olmayan ekonomilerdir. 1998 tarihli bu ilk raporu, dört farklı ilerleme raporu takip etmiş ve ilk ilerleme raporu 2000 yılında yayınlanmıştır. Bu raporda; OECD ülkeleri içinde, altmış yedi tane potansiyel olarak zararlı vergi rejiminin bulunduğu, ayrıca otuz beş ülkenin vergi cenneti kriterlerine uyduğu tespit edilmiştir.

2001 yılında yayınlanan İkinci ilerleme Raporunda, vergi cennetleri için yürütülen çalışmada bir takım önemli değişiklikler yapılmıştır. İkinci Raporda; OECD ile işbirliği içerisinde olmayan bir ülkenin vergi cenneti olarak tanımlanmasında, etkin bilgi değişimine ilişkin taahhütlerin ve şeffaflığın kriter olarak aranacağı belirtilmiştir. 
2000-2004 yılları arasında OECD, birtakım uygulamalar geliştirmiştir. Bu uygulamalar mevcut ya da gelecekteki tercihli rejimleri gözden geçirmek için ve 1998 Raporunda öngörülen kriterlerin herhangi birinin mevcut olup olmadığını değerlendirmek için, üye ülkelere yardımcı olmuştur. Uygulamalar yoğunlukla şeffaflık, bilgi değişimi, finansal koruma (ring-fencing), transfer fiyatlandırması, yönetim, holding işletmeler ve fon idaresi ekseninde yoğunlaşmıştır.

2004 yılı başında, OECD Üçüncü İlerleme Raporunu yayınlamış ve üye ülkelerdeki tercihli rejimlerin zararlı yönlerini bertaraf etmelerine yönelik gelişime odaklanmıştır. Üçüncü illerleme Raporu, 2000 yılında tanımlanan altmış yedi rejime ek olarak holding işletmeleri ve benzeri tercihli rejimleri de kapsamıştır. Üçüncü İlerleme Raporunda, bu rejimlerden on sekizinin, rejimlere sahip olan ülkeler tarafından, kaldırılmış veya kaldırılma aşamasında olduğu belirtilmiş ve diğer rejimlerin ise yapılan değerlendirme neticesinde zararlı olmadığına karar verilerek bu rejimlerin hiçbiri 1998 raporu kapsamında zararlı bulunmamıştır. 2006 yılında yayınlanan Dördüncü ve Son Illerleme Raporunda ise, sadece bir rejimin zararlı olduğu hükmü ortaya konmuştur.

Vergi cennetleri ile ilgili çalışmalar 2000'li yılların başında, vergiye ilişkin konularda OECD üyesi olmayan ülkeler ile diyalog kurmak üzere oluşturulan- Küresel Forum (Global Forum) vasıtasıyla artmıştır. Etkin bilgi değişimi ve şeffaflık taahhütlerinde bulunan ülkeler ile OECD üyesi olan ülkeler etkin bilgi değişimi ve şeffaflık hakkında daha gelişmiş prensipler ortaya koymak ve bunların uygulanmasını sağlamak üzere Küresel Forum'a davet edilmiştir. Küresel Forum, 2002 yılında "Vergilendirmeye illişkin Konularda Bilgi Değişim Anlaşmalarını" geliştirmiş ve 2005 yılında şeffafık konusunda bilgilerin ulaşılabilirliği ve güvenirliği ile bağlantılı standartları kabul etmiştir. 2006 yılına kadar Küresel Forum, standartların uygulanması sürecine ilişkin değerlendirmelerini yıllık olarak yayınlamıştır.

2009 yılında Küresel Forum, "Vergi Amaçlı Bilgi Değişimi ve Şeffaflık Küresel Forumu" olarak yeniden adlandırılmış ve üyeleri ve denetimi altında bulunanlar ülkeler üzerindeki denetim yetkisini geliştirici bir biçimde yeniden yapılandırılmıştır. Nihayet, 2015 yılında Peru'da gerçekleştirilen G20 Maliye Bakanları toplantısında OECD Sekretaryası, BEPS projesine ilişkin uzlaşılan eylemleri sistematikleştiren on beş nihai raporu yayınlamıştır.

Çalışmaya konu BEPS- 5 Numaralı Nihai Raporu; şeffaflığın geliştirilmesi amacı ile, tercihli rejimlerdeki idari kararları "zorunlu ve spontane bilgi değişimi" kapsamına almış, bilgi değişimine konu kararların net biçimde çerçevesini çizmiş ve idari kararların ne şekilde alınması ve uygulanması gerektiği hususunda rehberlik yapmak üzere "en iyi uygulamalar" taslağı geliştirmiştir.

\section{OECD-BEPS 5 Numaralı Eylem Planı Nihai Raporu Kapsamında "Vergi Şeffaflığına" ilişkin Düzenlemeler}

\section{1. "Şeffaflık" Kavramı}

"Şeffaflık" kavramı Türk Dil Kurumu sözlüğünde "saydamlık, saydam olma durumu" olarak tanımlanmıştır (Türk Dil Kurumu Sözlüğü, 2017). 
Vergi hukuku doktrininde ele alınmayan şeffaflık ilkesi, ulusal hukukta daha çok idare hukukunda özellikle kamu ihale hukuku alanında karşımıza çıkmaktadır. Kamu ihale hukukunda şeffaflık ilkesi, ihale ilanı ve tekliflerin kamuya açık yani aleni biçimde yapılmasını öngörür (Gözler, 2009: 113). Ayrıca idari usul ilkesi olarak da karşımıza çıkan şeffaflık, idarenin karar alma sürecinde yapılan bütün müzakerelerin ve kurul toplantılarının kamuya açık olmasını öngörür (Yıldırım vd., 2010:187). Bir diğer tanıma göre ise şeffaflık; siyasal ve yönetsel bakımdan, devletin faaliyetlerine ilişkin güvenilir, konu ile ilgili bilginin vaktinde halk tarafından elde edilebilmesi anlamına gelmektedir (Kondo, 2002: 7).

Yukarıdaki açıklamalara dayanılarak idare hukuku doktrininin ilkeyi; idari işlemlerin kamuya açık/aleni biçimde gerçekleştirmesi ile bağlantılı olarak anlamlandırdığını söylemek mümkündür.

OECD’nin İstatistiksel Terimler Sözlügüne göre şeffaflık: Yasal, kurumsal ve ekonomik sistemin, politik kararların ve bunların dayanaklarının, para ve maliye politikaları ile ilgili verilerin/bilgilerin, kurumların sorumluluk şartlarının, açık/anlaşıır ve zamanında erişilebilir biçimde kamuya açık olması amacını taşıyan bir ortamı ifade eder (OECD Glossary of Statistical Terms, 2017).

1998 tarihli rapora göre şu hallerde bir ülkenin şeffaflıktan yoksun olduğu söylenebilir: Bir ülkede, belirli bir sektöre diğer sektörlere nazaran- daha düşük oranda vergilendirme gibi- vergi avantajları sağlayan idari işlemler söz konusu ise, idari uygulamalar yasaların öngördüğü temel usullere aykırı (gizli) biçimde yapılıyorsa veya ülke içerisindeki genel mali ortam ulusal vergi yasalarının uygulanmadığını gösteriyorsa. Aynı raporda OECD, bir ülkenin vergi idaresinin şeffaf sayılabilmesi için, o ülkedeki vergi düzenlemelerinin kime hangi koşullarda uygulanacağının, kesin ve idareye karşı ileri sürülebilir biçimde açık olması gerektiğine dikkat çekmiş ve bir ülkede hangi vergi mükellefinin hangi kurallara tabi olduğuna ilişkin vergi rejiminin detaylarının, ilgili diğer yabancı vergi idareleri tarafından ulaşılabilir olması gerektiğine değinmiştir. Şu halde OECD'nin şeffaflık kavramını, vergilendirmeye ilişkin idari uygulamaların eşitlik ve yasallık ilkelerine uygunluğu ve kamuya açıklığı ile ilişkilendirdiği sonucuna varılabilir.

Şeffaflık, esas itibariyle hükümetler ile özel hukuk kişileri arasındaki ilişkiyi tanımlayıcı ve ayrıştırıcı bir ifadedir (Kudrle, 2016:1168). Bu anlamının yanında, kavram uluslararası vergi hukuku literatüründe daha çok, özel hukuk kişilerinin ekonomik durumlarına ilişkin bilgilerin toplanması ve paylaşılması ile ilişkilendirilmiştir (Kudrle, 2016: 1168). Şeffaflık kavramı, OECD’nin haksız vergi rekabeti ve vergiden kaçınma üzerine odaklanması sonucunda vergi hukuku alanındaki bugünkü karşılığına evrilmiştir (Kudrle, 2016: 1168).

Vergi şeffaflığı, agresif vergi planlaması ile mücadelede önemli bir unsur olarak karşımıza çıkmaktadır. Günümüzde özellikle kurumların vergilendirilmesinde, ülkelerin şeffaf olmayan uygulamalara sıklıkla başvurduğu gözlemlenmektedir. Yatırımcılarının kimlik bilgilerini paylaşma konusunda şeffaf olmayan bir vergi rejimi; hem verginin kaçırılmasına hizmet eder hem de vergiden kaçınma amacıyla esası olmayan görünürde işlemlerin yapılmasına neden olur (Kudrle, 2016: 1154). Bu nedenle OECD, şeffaflık 
üzerine çalışmalar yürütmüş ve BEPS- 5 Numaralı Eylem Planı Nihai Raporunu 2015 yılında yayınlamıştır.

BEPS- 5 Numaralı Eylem Planı ile OECD; zararlı vergi uygulamalarıyla ilgili 1998 kriterlerinin gözden geçirilmesi, bu tür uygulamaların tespit edilmesi ve bunlarla mücadelede yeni çerçevelerin çizilmesi konusunda oldukça ilerleme kaydetmiştir (Liebman vd, 2016: 103). Şeffaflığın artırılması taahhüdünün bir sonucu olarak; Nihai Raporda, üye ülkeler arasında, mükelleflere özgü vergi uygulamalarının spontane ve zorunlu biçimde bilgi değişimine konu olmalarının kapsamlı bir çerçevesi çizilmiştir (Liebman vd, 2016: 103).

\subsection{Zorunlu ve Spontane Bilgi Değişimi}

\subsubsection{Genel Olarak}

BEPS- 5 Numaralı Eylem Planı Nihai Raporu ile OECD, üye ülkeler ve iş birliği içerisinde olunan ülkelere, belirli kategorideki idari kararların zorunlu ve spontane biçimde yine raporda öngörülen ülkeler ile değiştirilmesi sorumluluğunu yüklemiştir.

İdari karar kavramından ne anlaşılması gerektiği hususu Nihai Raporda düzenlenmiştir. Buna göre idari karar; belirli bir vergi mükellefine veya mükellef bir gruba vergi statüleri ve bu statüde bulunmaları dolayısıyla elde ettikleri haklara ilişkin vergi idaresi tarafından verilen taahhüt, bilgi veya tavsiyelerdir. İdari kararlar, mükellefe özgü idari kararlar ve genel nitelikli kararlar olmak üzere ikiye ayrılır.

Nihai Rapora göre mükellefe özgü idari kararlar, sadece belirli mükelleflere uygulanan ve belirli mükellefler için hak sahipliği doğuran kararları ifade eder. Bu kararlar faaliyet öncesi veya sonrasına ilişkin olabilir. Bu kararlar, mükellefin defterleri ve belgeleri veya hesapları üzerinde yapılan bir vergi denetimi neticesinde gerçekleştirilen uzlaşma ve benzeri anlaşmaları ve beyanları kapsamaz. Ancak denetim sonucu verilmiş olmakla birlikte, raporda öngörülen kategorilerden birine giren ve mükellefe geleceğe yönelik fayda sağlayıcı nitelikte bir karar zorunlu ve spontane bilgi değişimi yükümlülüğünün kapsamına dahil olacaktır.

Peşin vergi kararları ve peşin fiyatlandırma anlaşmaları mükellefe özgü kararlardır. Peşin vergi kararları ile belirli mükelleflerin gerçekleştirmeyi tasarladıkları işlemlerin vergisel sonuçları saptanır. Mükelleflere özgü kişisel nitelikteki bu kararlara, Türk Vergi Hukuku'ndaki özelgeler örnek olarak verilebilir. Peşin vergi kararları pek çok farklı formda olabilir. Örneğin; bir hukuki işlem veya idari bir uygulamanın parçası olarak verilen kararlar ve izinler bu kapsamdadır. Benzer şekilde gayri resmi olarak verilen kararlar da bu kapsamda değerlendirilebilir. Peşin vergi kararları çoğunlukla belirli bir mükellefin gerçekleştirmeyi tasarladığı faaliyete, hukukun veya idari uygulamaların ne şekilde uygulanacağı gösterir. Bu tür kararlar, mükellefin kişisel durumunu göz önüne aldıklarından ilgili vergi mükellefi için özel olarak hazırlanmıştır ve bu nedenle diğer vergi mükelleflerine doğrudan uygulanmazlar.

Peşin fiyatlandırma anlaşmaları ise kontrollü işlemlerin öncesinde, söz konusu işlemler için sabit fiyat üzerinden transfer fiyatının belirlenmesine yönelik anlaşmalar olarak tanımlanmaktadır (Başaran Yavaşlar, 2012: 293). Bu düzenlemeler, transfer 
fiyatlandırması kurallarının mükelleflerin gelecekteki işlemlerine nasıl uygulanacağı konusunda, mükelleflere güvence sağlamaktadır. Tek taraflı, iki taraflı veya çok taraflı olabilen peşin fiyatlandırma anlaşmaları için başvuruda bulunanlar; anlaşmanın kapsamına giren endüstri, pazar ve ülkeler ile ilgili olarak vergi idarelerine, tasarladıkları işlemin ayrıntıları, karşılaştırılabilir nitelikte olabilecek tüm işlemler ve bunların işlevsel bir analizi ile ilgili belgeleri sağlarlar. Kısaca değinmek gerekir ki, iki taraflı ve çok taraflı peşin fiyatlandırma anlaşmaları uluslararası anlaşma niteliğine sahip iken tek tarafı peşin fiyatlandırma anlaşmalarının hukuki niteliği açık değildir (Başaran Yavaşlar, 2012: 296). Nihai Rapor, tek taraflı peşin fiyatlandırma anlaşmalarını birer idari karar olarak nitelendirerek zorunlu ve spontane bilgi değişimi yükümlülüğü kapsamına dahil etmiştir.

Genel nitelikli kararlar ile vergi idareleri, kanunların ve idari uygulamaların bir mükellef gruba veya faaliyete ne şekilde uygulanacağına ilişkin yorumda bulunarak mükelleflere rehberlik etmektedirler. Bu tür kararlar, zorunlu ve spontane bilgi değişiminin kapsamı dışında bırakılmıştır. Ayrıca değinmek gerekir ki gerçek kişilerin gelir vergilerine ilişkin idari kararlar da zorunlu ve spontane bilgi değişiminin konusunu teşkil etmez.

\subsubsection{Zorunlu ve Spontane Bilgi Değişimine Konu İdari Kararlar}

Nihai Rapor sadece mükellefe özgü kararların zorunlu ve spontane bilgi değişimine konu olacağını belirttikten sonra, yükümlülüğün kapsamına giren kararları altı kategoriye ayırmıştır. Bunlar; tercihli rejimlere ait mükellefe özgü kararlar, yabancı kaynaklı tek tarafı ı pşin fiyatlandırma anlaşmaları ve diğer yabancı kaynaklı tek tarafı vergi kararları, vergi mükellefinin mali/ticari hesaplarına doğrudan yansımayan ve vergilendirilebilir kazançlarını tek taraflı olarak azaltma imkânı sağlayan yabancı kaynaklı kararlar, daimi işyeri kararları, ilişkili aracı kuruluş kararları ve FHTP' nin (Forum of Harmful Tax Practices: Zararlı Vergi Uygulamaları Forumu) değişimin olmaması halinde, BEPS açısından sakıncalı olacağını öngördüğü diğer kararlardır.

Yukarıda bahsi geçen karar kategorilerinden ilki tercihli rejimlere ait mükellefe özgü kararlardır.

Tercihli rejim kavramına bu noktada kısaca değinmek gerekir. Bazı ülkeler vergilendirme rejimleri ile klasik anlamda vergi cenneti tanımına girmemekle beraber, çok uluslu işletmeleri ülkelerine çekebilmek için bunlara bir takım vergi teşvik ve avantajları sağlamaktadır (Öz, 2005: 124). Tercihli vergi rejimleri olarak adlandırılan atipik rejimler, ülkelerin standart vergi kurallarının yanında onlara kıyasla, belirli tip kurumlar veya faaliyet türleri için daha fazla fayda sağlar. Bunlara örnek olarak; taşımacılık şirketi rejimleri, bankacılık rejimleri, sigorta rejimleri, finansman rejimleri ve finansal kiralama rejimleri, fon yönetimi rejimleri, şirket merkezi rejimleri, dağıtım merkezi rejimleri, hizmet merkezi rejimleri, holding işletme rejimleri, fikri mülkiyet rejimleri verilebilir.

OECD 1998 tarihli raporunda tercihli vergi rejimlerinin şu temel özellikleri taşıması gerektiği yönünde görüş bildirmiştir: Sıfır oranında veya düşük oranlı vergi uygulamaları, şeffaflıktan yoksunluk, etkili bilgi değişiminden yoksunluk ve finansal 
koruma (ring-fencing). Görüldüğü üzere bir tercihli vergi rejiminin karakteristik özellikleri, vergi cennetlerinin karakteristik özelliklerinden "finansal koruma" ile ayrılmaktadır. Bir diğer ifade ile OECD’nin 1998 tarihli raporunda "zararlı vergi uygulamaları" şemsiyesi altında yer verdiği iki konu yani tercihli vergi rejimleri ve vergi cennetleri neredeyse aynı temel karakteristik özellikleri taşımaktadır. Vergi cennetlerinin aksine tercihli vergi rejimlerinde ayırt edici özellik olarak belirtilen finansal koruma, bir finansal düzenleme konseptidir (Schwarcz, 2013: 73). Finansal korumanın en temel işlevi, bir şirketin iflas ile bağlantılı borçlara ve diğer risklere maruz kalmamasını sağlamaktır (Schwarcz, 2013: 73).

Yukarıdaki temel unsurlara ek olarak OECD 1998 raporunda, tercihli vergi rejimlerinin tanımlanmasında yardımcı olabilecek diğer bir takım özelliklere de yer vermiştir. Bunlar: vergi matrahı tanımının muğlak olması, uluslararası kabul gören transfer fiyatlandırması ilkelerine uyulmaması, mukim olunan ülkede vergiden istisna edilmiş yabancı kaynaklı gelirlerin olması, vergi oranının veya matrahının pazarlığa açık olması, gizliliğin mevcut olması, geniş bir vergi anlaşmaları ağına erişimin mümkün olması, rejimin vergiyi azaltan bir araç olarak teşvik edici olması, rejimin vergi odaklı ve gerçek faaliyet içermeyen işlem ve anlaşmaları desteklemesidir.

OECD’nin 1998 tarihli raporuna göre; bir vergi rejiminde düşük/sıfır oranlı vergi uygulaması mevcutsa ve bunun yanında -diğer unsurlar bakımından yapılan genel bir değerlendirme neticesine- bir veya daha fazla unsur tespit edilebiliyorsa, aynı zamanda rejimin zararlı ekonomik etkileri söz konusu ise, o rejim potansiyel olarak zararlıdır. Bir faaliyetin, gerçek bir üretim yapmak yerine tercihli vergi rejiminden faydalanmak amacıyla bir ülkeden diğerine kaydırılıp kaydırılmadığı; ev sahibi ülkedeki faaliyetin düzeyi ve seviyesi ile yatırımın/gelirin miktarının orantılı olup olmadığı; bir faaliyetin konumunun belirlenmesinde tercihli rejiminin öncelikli motivasyon kaynağı olup olmadığı soruları, bu aşamada değerlendirmenin yapılması için yardımcı olabilecektir. Düşük/sıfır oranlı vergi uygulamalarının belirleyici özellik olarak dikkate alınması, 2001 Ilerleme Raporunda vergi cennetleri bakımından sona ermiştir ancak tercihli vergi rejimleri için hala geçerliliğini sürdürmektedir.

FHTP, 2014 illerleme Raporunda tercihli rejimlerle ilgili kararlarda zorunlu olarak bilgi değişimini öngören bir taslağı kabul etmiştir. Buna göre; FHTP' nin çalışmaları kapsamında bulunan, düşük oranda veya sıfır oranında vergi uygulamaları bulunan tercihli rejimlere ilişkin yabancı mükelleflere özgü kararlarda, spontane biçimde bilgi alışverişinde bulunulması zorunluluğu bulunmaktadır. Kararlar yürürlüğe girdiği anda, bilgi değişimi yükümlülüğü de doğmaktadır.

Spontane bilgi değişimi yükümlülüğü, tercihli rejimlerle ilişkili herhangi bir karardan kaynaklanabilir. Bu rejimin 1998 Raporu çerçevesinde potansiyel olarak veya gerçekten zararlı bulunup bulunmadığının, yükümlülüğün doğması bakımından herhangi bir etkisi yoktur.

Henüz FHTP tarafından değerlendirilmemiş olan, ancak tercihli vergi rejimine sahip olan bir ülkenin kendi öz denetimini yapması veya FHTP' den görüş alması Nihai Raporda önerilmektedir. 1998 tarihli raporda öngörülen karakteristik özellikleri taşıyıp taşımadığı konusunda şüphe içerisinde olan devlete, spontane bilgi alış verişinde 
bulunması tavsiye edilir. Böyle bir durumda tercihli rejime sahip ülkenin kendi denetimini FTHP' den istemesi OECD tarafından beklenmektedir.

FTHP' nin şeffaflığın geliştirilmesine yönelik 2015 tarihli Nihai Raporu, 2014 yılı ilerleme Raporunu revize etmiş ve bazı kararlara ilişkin prosedürleri kapsamakla beraber, altı kategoride karara odaklanarak ilerleme raporundaki kapsamı sadeleştirmiş ve 2014 yılında yayınlanan raporun yerine geçmiştir.

Zorunlu ve spontane bilgi değişimine konu olan bir diğer karar türü, yabancı kaynaklı tek taraflı peşin fiyatlandırma anlaşmaları ve diğer yabancı kaynaklı tek taraflı vergi kararlarıdır. Transfer fiyatlandırması ve transfer fiyatlandırması ilkelerinin uygulanması kararları bu kapsamdadır.

Yabancı kaynaklı tek taraflı peşin fiyatlandırma anlaşmaları; OECD’nin Çok Uluslu İşletmeler ve Vergi İdareleri İçin Transfer Fiyatlandırması Rehberi'nde "kontrol altındaki işlemlere ilişkin transfer fiyatlandırmasının peşinen belirlenmesine yönelik uygun bir dizi kriteri (yöntem, karşılaştırılabilir unsurlar gibi kriterler) belirlemeye ilişkin ve belirli bir zaman dilimi için geçerli olan bir düzenleme" şeklinde tanımlanmıştır(Başaran Yavaşlar, 2012: 294). Peşin fiyatlandırma anlaşmaları; eğer iki devlet arasında ise iki taraflı, ikiden fazla devlet arasında ise çok taraflı, bir veya birden fazla mükellef ile bir vergi idaresi arasında ise tek taraflıdır(Başaran Yavaşlar, 2012: 294). Tek taraflı olmak koşulu ile yabancı kaynaklı bir işletme ile yapılan peşin fiyatlandırma anlaşmaları zorunlu ve spontane bilgi değişiminin konusunu oluşturur.

Diğer yabancı kaynaklı tek taraflı vergi kararları; transfer fiyatlandırması kararlarını veya transfer fiyatlandırması ilkelerinin uygulanmasına yönelik idari kararları ifade eder.

Nihai raporda belirtildiği üzere peşin vergi kararları, peşin fiyatlandırma anlaşmaları kadar etkili bir idari karar türü değildir. Çünkü bu tip kararlar, vergi mükellefinin sunduğu olgulara dayanarak, mükellefin hukuki nitelikteki sorularına cevap vermekle sınırlıdır. Peşin vergi kararları sadece belirli işlemler için bağlayıcıdır. Bu tip kararlar peşin fiyatlandırma anlaşmalarından ayrı olarak, genellikle birkaç farklı işlemi veya sürekli işlem bazında çeşitli işlemleri kapsar.

Nihai Rapora göre; tek taraflı peşin fiyatlandırma düzenlemeleri ve diğer tek tarafı vergi kararları, tercihli oldukları için değil, şeffaflı̆̆ın olmaması halinde uyumsuzluğa ve BEPS düzenlemelerine aykırılığa neden olacakları için spontane biçimde değiştirilmelidir. Bu tip anlaşmaların ve kararların şartları, kararın etki ettiği vergi mükellefleriyle ilgilenen vergi idarelerine açık olmazsa, bir işlemin nasıl fiyatlandırıldığı ve vergilendirildiğiyle ilgili uyumsuzluklar doğar. Bu karar kategorisi ile otomatik bilgi değiştirme yükümlülüğü ve BEPS- 13 Numaralı Eylem Planında ele alınan transfer fiyatlandırması dokümantasyon gereksinimleri arasında yakın bir ilişki vardır.

BEPS- 13 Numaralı Eylem Planı transfer fiyatlandırması için üç aşamalı bir belgeleme/dosyalama standardı (ana dosya, yerel dosya ve ülke bazlı raporlama) oluşturmayı amaçlamıştır. İşletmelerce hazırlanacak ana dosya, küresel düzeyde vergi idarelerine uluslararası işletmelerin faaliyetleri ve transfer fiyatlandırması politikaları ile ilgili bir genel bilgi sağlarken, yerel dosya yerel vergi idarelerine transfer fiyatlandırması işlemlerinin detaylarını gösterir(Lei, 2017: 18). Ülke bazlı raporlama ise, işletmelerin 
ünvanları, faaliyet bilgileri, gelir miktarları, çalışan sayıları gibi bir takım temel bilgilerin yıllık bir rapor ile ilgili vergi idarelerine bildirilmesini sağlar (Lei, 2017: 18). Bu belgeleme standardı, transfer fiyatlandırması faaliyetlerinin kapsamlı bir resmini ortaya koyarak, vergi idarelerine etkin araçları kullanarak vergi amaçlı kâr aktarımını önleme imkanı tanır (Lei, 2017: 18).

Nihai Raporda belirtildiği üzere zorunlu ve spontane bilgi değişimi ve ülke bazlı raporlama yükümlülüğü birbirini güçlendirerek, vergi idarelerine mükellefler tarafından verilen bilgileri bir başka vergi idaresinden elde ettiği bilgi ile çapraz denetleme imkânı vermektedir.

Zorunlu ve spontane bilgi değişimi yükümlülüğüne konu üçüncü karar kategorisi, vergi mükellefinin mali/ticari hesaplarına doğrudan yansımayan vergilendirilebilir kazançlarını tek taraflı olarak azaltma imkânı sağlayan yabancı kaynaklı kararlardır.

Nihai Rapora göre; mükelleflerin kazançlarını azaltıcı nitelikte düzenlemeler yapmalarına imkan tanıyan bir rejim, vergi gelirlerinin azalmasına neden olur. Bu durum çok uluslu işletmeleri kâr aktarımı yapma konusunda teşvik etme potansiyeline sahiptir. Bu teşvik, kazanç üzerinde azaltıcı nitelikte düzenlemenin öngörülebilir olduğu yerlerde, örneğin kararların veya diğer idari uygulamaların bir parçası olunan durumlarda ortaya çıkar. Bu gibi durumlarda, etkili bilgi alışverişi, diğer ülkelere transfer fiyatlandırması kurallarını uygulama fırsatı vermek için özellikle önemlidir.

Illave kazanca ilişkin kararlar, hukuka aykırı sermaye kararları veya benzeri diğer kararlar; sermayenin veya bir varlığın katkısını kabul eder. Örnek olarak, faizsiz bir kredinin olması durumunda varsayılan faiz indirimi yoluyla vergilendirilebilir kazancın azaltılması verilebilir. Bu durumun bir başka örneği, vergi cennetindeki iştirakin lehine olacak biçimde, ana şirkete emsallere uygunluk ilkesine aykırı biçimde düşük fiyatlı ödeme yapılmasıdır. Bu gibi durumlarda bir ülke, bağlı ortaklığın vergilendirilebilir kazançlarını azaltıcı etki doğuracak biçimde kararlar verebilir.

Nihai Rapora göre daimi işyeri kararları zorunlu ve spontane bilgi değişim yükümlülüğü kapsamındadır. Daimi işyeri kararları, daimi bir işyerinin varlığını veya yokluğunu açıkça ortaya koyan ve bir daimi işyerine ne kadar kâr atfedileceğini gösteren idari nitelikteki kararları ifade eder.

Nihai Rapor beşinci karar türü olarak ilişkili aracı kuruluş kararlarını saymıştır. İlişkili aracı kuruluş kararları, idari kararı veren ülkedeki bir kuruluşun yabancı kaynaklı fon veya gelir akışlarına ilişkin kararlarını kapsar. Örneğin; çok kademeli bir yerli kuruluşun, kendine bağlı bir alt işletmesinden yabancı kaynaklı gelir elde etmesi ve daha sonra bağlı olduğu üst kademeli yerel bir işletmeye kredi yoluyla faiz ödemesi yaparak vergi matrahını düşürmesine imkan tanıyan kararlar bu kapsamdadır. Bu örnekte üst kademeli işletme, ilgili ülkenin iç hukukunda vergi açısından şeffaf ve yalnızca yabancı ortakları olan bir işletme olarak değerlendirilebilir ve dolayısıyla vergiden kaçınmak mümkün hale gelir. Bu tip idari kararların zorunlu ve spontane biçimde değiştirilmesi Nihai Rapora göre şeffaflı̆̆ın gelişmesine hizmet edecektir.

Son olarak Nihai Raporda, FHTP'nin, değişimin olmaması halinde, BEPS açısından sakıncalı olacağını öngördüğü diğer idari kararlar sayılmıştır. Bu kategorideki kararlar gelecekte zorunlu ve spontane bilgi değişimi yükümlülüğünün kapsamının 
genişletilmesi için FHTP'ye esneklik sağlamak amacı ile oluşturulmuştur. İçeriği OECD tarafından henüz doldurulmamış olan bu kategori, gelecek zamanlarda -yukarıdaki diğer idari karar türleri kapsamına girmemekle birlikte- ortaya çıkabilecek yeni idari karar türlerinin BEPS açısından sakıncalı görülmesi halinde zorunlu ve spontane bilgi değişimine konu olması amacı ile oluşturulmuştur.

\subsubsection{Zorunlu Ve Spontane Bilgi Değişimi Süreci}

OECD'nin; BEPS' in gerekliliklerinin icra edilmesi hususunda tüm G20/OECD üye ülkelerinden ve OECD ile işbirliği içerisinde bulunan ülkelerden beklentisi, bu ülkelerin iç hukuklarını, BEPS dolayısı ile ortaya çıkan yükümlülüklerine uygun hale getirmeleridir.

OECD üye ülkelerinin ve OECD ile işbirliği içerisinde bulunan ülkelerin; Nihai Raporda sayılan kategorilerdeki bir idari kararı uygulamaları halinde, bu bilgiyi hangi ülkelere bildirmeleri gerektiği hususu Nihai Raporda aydınlatılmıştır. Nihai Rapora göre, bilgi almaya yetkili olanlar öncelikle vergi mükellefinin (hakkında idari karar uygulaması bulunan) işlem gerçekleştirdiği ilişkili kişilerin mukim oldukları ülkelerdir. Ayrıca tercihli bir rejimden yararlanan ilişkili kişilerden gelir elde edenlerin, mukim oldukları ülkeler de (buna daimi işyerleri de dahildir) bilgi almaya yetkilidirler. Son olarak, hakkında idari karar uygulanan işletmenin bağlı olduğu birincil kademedeki ve en yüksek kademedeki (çoğunlukla şirket ana merkezidir) işletmelerin mukim bulunduğu ülkeler bilgi alma hakkına sahiptirler.

Her bir karar kategorisi bakımından bilgi almaya yetkili olan ülkeler tek tek ele alınacak olursa;

- Tercihli rejimlere ait mükellefe özgü kararlar; ilişkili kişilerin mukim olduğu ülkeler, işletmelerin bağlı olduğu birincil ve en yüksek kademedeki işletmelerin mukim oldukları ülkeler,

- Yabancı kaynaklı tek taraflı peşin fiyatlandırma anlaşmaları ve diğer yabancı kaynaklı tek taraflı vergi kararları; mükellefin peşin fiyatlandırma anlaşmaları veya tek taraflı yurt dışı kaynaklı kararlar kapsamına giren işlemlere giriştiği ilişkili kişilerin mukim oldukları ülkeler, işletmelerin bağlı olduğu birincil ve en yüksek kademedeki işletmelerin mukim oldukları ülkeler,

- Vergi mükellefinin mali/ticari hesaplarına doğrudan yansımayan vergilendirilebilir kazançlarını tek taraflı olarak azaltma imkânı sağlayan yabancı kaynaklı kararlar; kararın kapsamına giren işlemin gerçekleştirildiği ilişkili kişilerin mukim oldukları ülkeler, işletmelerin bağlı olduğu birincil ve en yüksek kademedeki işletmelerin mukim oldukları ülkeler,

- Daimi işyeri kararları; yönetim merkezlerinin ve daimi işyerlerinin mukim oldukları ülkeler, işletmelerin bağlı olduğu birincil ve en yüksek kademedeki işletmelerin mukim oldukları ülkeler,

- İlişkili aracı kuruluş kararları; mükellefe doğrudan veya dolaylı olarak ödeme akışı gerçekleştiren ilişkili kişinin mukim olduğu ülke, ödemelerin yapıldığı şirket ana 
merkezinin mukim olduğu ülke ve işletmelerin bağlı olduğu birincil ve en yüksek kademedeki işletmelerin mukim oldukları ülkeler

ile değiştirilmelidir.

Nihai Rapora göre bir işletme doğrudan veya dolaylı olarak bir başka işletmede \%25 veya daha fazla oranda yatırıma sahip ise her iki işletme ilişkili kişi sayılır. Bu oran dikkate alınırken, kar payı, oy hakkı veya kişiye bu payın karşılığı olarak sağlanan herhangi bir menfaatin değeri dikkate alınabilir.

Zorunlu ve spontane bilgi değişimi yükümlülüğü yalnızca gelecekteki kararlar için değil aynı zamanda önceki yıllara ilişkin geçmiş kararlar için de geçerlidir. 1 Ocak 2010 tarihinde veya sonrasında çıkarılan ve 1 Ocak 2014'ten itibaren hala yürürlükte olan idari kararlar ile ilgili bilgilerin değiştirilmesi konusunda nihai raporda mutabakata varılmıştır. Nihai rapora göre, zorunlu ve spontane bilgi değişimi idari kararın uygulama tarihinden itibaren en geç üç ay içerisinde yapılmalıdır.

Nihai Rapor ayrıca; ülkelerin iç hukuklarında bir takım değişiklikler yapma gereği doğabileceğini dikkate almıştır. Dolayısı ile ülkelerin gelecekteki kararlar bakımından bilgi değiştirme yükümlülükleri 1 Nisan 2016 tarihinde veya sonrasında verilen kararlar için geçerlidir.

\subsection{En İyi Uygulamalar}

Nihai Rapor belirli kategorideki idari kararların etkilenen ülkeler ile değiştirilmesi hususunu detaylı bir biçimde aydınlatmıştır. Bunun akabinde, üye ülkelere ve iş birliği içerisinde olunan ülkelere "idari kararların" hukuka uygun olarak en ideal biçimde ne şekilde alınacağı hususunda rehberlik etmek amacıyla bir "en iyi uygulamalar" taslağı geliştirmiştir.

En iyi uygulamalar taslağına göre şeffaf bir vergi rejiminde bir "idari kararın" hukuka uygun olması için karar sürecine etki edecek yasalar ve idari prosedürler, temel unsurları içerir biçimde, önceden yayınlanmış olmalıdır. Ayrıca karar sürecinde idarenin takdir yetkisinin kullanılması söz konusu ise, takdir yetkisinin sınırları yasa ile belirlenmiş olmalı ve yetki bu sınırlara uygun biçimde kullanılmalıdır.

Nihai Rapora göre idari kararlar, ikili anlaşmalar gibi, iç hukuka uygulanabilir uluslararası yükümlülüklere uygun olmalı ve yazılı biçimde verilmelidir. Ayrıca raporda, bir kararın uygulanması için karar sürecine en az iki yetkili kişinin dahil olması veya karar sürecinin en az iki seviyeli bir incelemeye tabi olması önerilmektedir. Kararın verilmesi sürecinde daha önce benzer konularda gözetilen yasalar ve idari uygulamalar dikkate alınarak kararlarda tutarlılık sağlanmalıdır.

Mükellefler, talep ettikleri idari kararlar için başvurularını, işlemlerinin veya faaliyetlerinin temelini açıkça ortaya koyan yazılı belgeler ile yapmalıdır. Başvurucular ile ilgili bilgiler (unvan, ikametgah, ticaret sicil numarası gibi) -vergi danışmanının bilgilerini içerir biçimde-kararların dosyasına eklenmelidir. Bir karar alınmadan önce, yetkili kişi, tanımlanan olgu ve olayların açık biçimde çerçevesinin çizilip çizilmediğini ve kararın sonuçlarının öngörülebilir olup olmadığını teyit etmelidir. 


\section{Sonuç}

Dünya finansal varlığının azımsanamayacak bir bölümünün çok uluslu işletmeler eliyle, vergi cenneti ülkelere aktarılması, gelişmiş ve gelişmekte olan ülkelerin ekonomilerini ciddi anlamda olumsuz etkilemiştir. Bu olumsuz etki ülkeleri, işbirliği içerisinde, vergi cennetleri ile mücadele etmeye sevk etmiş ve problemi uluslararası kuruluşların gündemine taşımıştır. OECD, vergi cennetleri ile mücadelesini 1998 tarihinde başlatmış ve mücadelesinde bugüne kadar ciddi ilerlemeler kaydetmiştir. BEPS-5 Numaralı Eylem Planı, bugün itibariyle vergi cennetleri ile mücadelede gelinen noktanın önemli bir parçasıdır.

Farklı ülke ve kuruluşlarca yayınlanmış vergi cennetleri listeleri dikkate alındığında, vergi cennetini tanımlayıcı karakteristik özellikler konusunda henüz bir ortak kanaate varılmadığı tespitini yapmak mümkündür. Nitekim çalışmaları süresince OECD dahi, vergi cennetlerinin taşıması gereken karakteristik özellikler konusundaki düşüncelerini değiştirmiştir. Hali hazırda bir ülkeyi vergi cenneti olarak nitelendirebilmek için şeffaflık ve etkin bilgi değişiminden yoksunluk özelliklerini belirleyici olarak kullanan OECD, BEPS projesi ile hem şeffaflığın geliştirilmesi hem de bilgi değişimi konularında yoğun çalışmalar yürütmüştür.

Şeffaflığın geliştirilmesi sürecinde, uluslararası kuruluşlar öncelikle çift taraflı bilgi değişim anlaşmalarının yaygınlaşmasına odaklanmıştır. Ancak bu anlaşmaların, çift taraflı yapısı bir diğer ifade ile anlaşmaların sadece taraflarını bağlamaları, şeffaflığı geliştirici etkilerini oldukça sınırlamıştır. Çift taraflı anlaşmaların sadece taraf ülkeleri bağlaması, bu anlaşmalara tarafı olmayan vergi cennetlerini, vergiden kaçınmak isteyen çok uluslu işletmeler nezdinde çekici hale getirmiştir. Vergi cennetlerinin artan cazibesi ise, uluslararası vergi hukukunda "şeffaflık" dalgasının yükselmesine neden olmuştur.

OECD’nin şeffaflık kavramını, vergilendirmeye ilişkin idari uygulamaların kamuya açıklığı ile bağlantılı olarak anlamlandırdığını söylemek mümkündür. OECD, 2015 tarihli BEPS- 5 Numaralı Eylem Planının Nihai Raporu ile, diğer uluslararası bilgi değişim yükümlülüklerinin aksine, belirli kategorilerdeki "idari kararların” zorunlu ve spontane biçimde değiştirilmesi öngörülmüştür. Nihai Raporda çerçevesi çizilen idari karar türlerinin, uygulama tarihinden itibaren ivedi bir biçimde karardan etkilenecek olan ülkeler ile değişimi, şeffaflığın gelişmesine hizmet eder. Bununla birlikte idari kararların uygulanmasından etkilenecek olan ülkelerin kararlar hakkında bilgi sahibi olması, vergi idarelerine mükelleflerini denetleme hususunda avantaj sağlayacaktır.

OECD’nin, zorunlu ve spontane bilgi değişimi yükümlülüğü konusunda üye ülkelerden ve OECD ile işbirliği içerisinde olan ülkelerden beklentisi, ülkelerin iç hukuklarını bilgi değişim yükümlülüklerini destekleyici biçimde revize etmeleridir. Bu durum bir OECD üye ülkesi olan Türkiye için de geçerlidir.

Şeffaflığın geliştirilmesi ile vergi cennetlerinin yüksek oranda etkinliklerini yitireceği tahmin edilebilir bir olgudur, tıpkı OECD ile bilgi değişimi hususunda iş birliği içerisinde olan pek çok ülkenin, yatırımcıları kendi ülkelerine çekmek için yeni oyun sahaları yaratmasının beklenilen bir durum olması gibi. Ancak, OECD aracılığıyla ve geniş çaplı bir işbirliği ile alınacak önlemlerin caydırıcı olacağı söylenebilir. 
Sonuç olarak, idari kararlara ilişkin bilgilerin bu kararlardan etkilenen ülkeler ile zorunlu ve spontane biçimde paylaşılmasının, şeffaflığın gelişmesine ve dolayısı ile vergi cennetleri ile mücadeleye hizmet edecek etkili bir araç olduğunu söylemek mümkündür.

\section{Kaynakça}

Arslan, M.(2011), "Vergi Cennetleri ve Küresel Yoksulluk", Vergi Raporu, No: 142 (Temmuz), ss. 42-48.

Başaran Yavaşlar, F. (2012), "Peşin Fiyatlandırma Anlaşmaları ve Bu Anlaşmaların Anayasal Sınırları", Marmara Üniversitesi Hukuk Fakültesi ve Deutscher Akademischer Austauschdienst (DAAD) tarafından düzenlenen "Uluslararası Tartışma Ortamında Transfer Fiyatlandırması" başlıklı uluslararası sempozyum, İstanbul, Mart 6

Bennedsen, M.\& Zeume, S. (2015). "Corporate Tax Havens and Transparency", https://www.chicagobooth.edu/ /media/4EFDF14CFE204FEB88670F9E0438B1 71.pdf, (10.02.2017).

Bilici, N. (2004). Türkiye'de Vergi Kayıp ve Kaçakları Önlenmesi Yolları, 19. Maliye Sempozyumu, Antalya, Mayıs 10-14, ss.601-620.

Desai Mihir, A. \& Foley, C. \& Hines J.R., Economic Effects of Regional Tax Havens, 2004, http://www.bus.umich.edu/otpr/WP2004-9.pdf, (05.02.2017).

European Parlıament (2013), Polici Department Budgetary Affairs, http://www.europarl.europa.eu/RegData/etudes/etudes/join/2013/490673/IP OL-JOIN_ET(2013)490673_EN.pdf, (05.04.2017).

Gözler, K. (2009), Idare Hukuku, 2.Baskı, 2.Cilt, Bursa, Ekin Yayınevi.

Harm, O. (2013), "International Tax Transparency: Past, Present and Future, http://www.internationaltaxreview.com, (15.03.2017).

Karakurt, B. (2016), "Vergi Cennetleri ve Posta Kutusu Şirketlerin Kamu Maliyesine Etkileri", Atatürk Üniversitesi Iktisadi ve Idari Bilimler Dergisi, No:2 (30), ss. 319341

Kondo, S. (2002). "Fostering Dialogue to Strengthen Good Governance". Public Sector Transparency and Accountability: Making it Happen. Paris.

Kudrle, R. (2016). "Tax Havens and the Transparency Wave of International Tax Legalization", University of Pennsylvania Journal of International Law, Vol. 19 (4), ss. 1153-1182. 
Lei, F. (2017). "Country by Country Reporting Under BEPS". The Contemporary Tax Journal, No: 6 (2), 17-20.

Liebman, H.\& Heyvaert, W.\& Oyen, W. (2016) , “Countering Harmful Tax Practices: BEPS Action 5 and EU Initiatives - Past Progress, Current Status and Prospects", https://www.ibfd.org/sites/ibfd.org/files/content/pdf/et_2016_2-3_e2_2.pdf, (02.02.2017).

Murphy, R. (2017). Dirty Secrets: How Tax Havens Destroy The Economy, London, Verso.

Organisation for Economic Co-operation and Development (1998), Harmful Tax Competition, Paris, https://www.oecd.org/tax/transparency/44430243.pdf, (02.02.2017).

Organisation for Economic Co-operation and Development (2000) , Towards Global Tax Co-operation: Progress in Identifying and Eliminating Harmful Tax Practices, Paris, http://www.oecd.org/ctp/harmful/2090192.pdf, (02.02.2017).

Organisation for Economic Co-operation and Development (2001) , The OECD's Project on Harmful Tax Practices: The 2001 Progress Report, Paris, https://www.oecd.org/ctp/harmful/2664450.pdf, (02.02.2017).

Organisation for Economic Co-operation and Development (2004), The OECD's Project on Harmful Tax Practices: The 2004 Progress Report, Paris, https://www.oecd.org/ctp/harmful/30901115.pdf, (02.02.2017).

Organisation for Economic Co-operation and Development (2015), Final Report: Countering Harmful Tax Practices More Effectively, Taking into Account Transparency and Substance, Paris, http://www.keepeek.com/Digital-AssetManagement/oecd/taxation/countering-harmful-tax-practices-moreeffectively-taking-into-account-transparency-and-substance-action-5-2015final-report_9789264241190-en, (02.02.2017).

Organisation for Economic Co-operation and Development, Glossary of Tax Terms, http://www.oecd.org/ctp/glossaryoftaxterms.htm, (05.02.2017).

Organisation for Economic Co-operation and Development, Glossary of Statistical Terms, https://stats.oecd.org/glossary/, (05.02.2017).

Organisation for Economic Co-operation and Development, Transfer Pricing Guidelines for Multinational Enterprises and Tax Administrations, Paris, 2010, http://www.keepeek.com/Digital-Asset-Management/oecd/taxation/oecdtransfer-pricing-guidelines-for-multinational-enterprises-and-taxadministrations-2010_tpg-2010-en\#page4, (03.03.2017)

Oxfam (2000). Tax Havens: Releasing the Hidden Billions for Poverty Eradication, Oxfam GB Policiy Paper, 29 January, Retrived from, http://www.policypractice.oxfam.org.uk, 2000

Öz, S., Uluslararası Vergi Rekabeti ve Vergi Cennetleri, 1.B, Ankara: Maliye ve Hukuk Yayınları, 2005 
Öztürk, S. \& Ülger, Ö. (2016), “Vergi Cennetlerinin Küresel Finansal Kriz Üzerine Ekonomik Etkileri: Vergi Kaçırma, Vergiden Kaçınma ve Kara Para Aklamadaki Rolü", Niğde Üniversitesi Iktisadi ve Idari Bilimler Fakültesi Dergisi, No:1 (9), ss. 237-254.

Schwarcz, L. (2013), "Ring-Fencing", Southern California Law Review, Vol:87 (69), 2013.

Starchild, A. (2016), Tax Havens for International Business, 1.Ed., Macmillan Press.

Türk Dil Kurumu Sözlüğü, http://tdk.gov.tr/, (03.03.2017).

Yıldırım, T.\& Yasin, M. \& Özdemir, H.E. \& Üstün, G. \& Okay, Ö. (2010), Idare Hukuku II, 1.Baskı, İstanbul: On İki Levha Yayıncılık.

Zucman Gabriel (2015), Vergi Cennetleri: Ulusların Gizli Zenginliği, Çev.Yasemin Özden Charles, İstanbul: Yordam Kitapçılık. 